\title{
VEGETATION CHARACTERIZATION IN GULLY AREAS AS BASIS FOR SOIL CONSERVATION
}

\author{
Caracterização da vegetação em áreas de voçorocas \\ como base para a conservação do solo
}

\author{
Plínio Henrique Oliveira Gomide ${ }^{1}$, Marx Leandro Naves Silva ${ }^{1}$, Gislene Carvalho de Castro ${ }^{2}$, \\ Cláudio Roberto Fonsêca Sousa Soares ${ }^{3}$, Anna Hoffmann Oliveira ${ }^{1}$, Nilton Curi ${ }^{4}$
}

\begin{abstract}
Gullies are an expression of intense environmental degradation, particularly soil and vegetation. The objective of this work was to characterize the natural regeneration and vegetation planted in gully areas in the south of Minas Gerais State, Brazil, so the distribution and occurrence of the species can generate useful information for an adequate diagnosis on the development stage of gullies and for soil conservation. The study involved the characterization of vegetation present in the different segments of the gully areas, the bed, the bare middle third (BMT), middle third with vegetation cover (MTVC), and a fragment of native vegetation (FNV) located closer to the gully areas and adopted as a reference. In the gully area 3, the sampling took place in locations that were implanted with eucalyptus and candeia (Eremanthus erythropappus) vegetation, being these segments here termed as middle third with eucalyptus (MTE) and the middle third with candeia (MTC). Water erosion has impacted the plant cover, as well as some of the soil attributes, especially in BMT segment, where the vegetation has been eliminated, mainly due to the decreased levels of geometric mean diameter (GMD) of aggregates, soil hydraulic conductivity (Ks), low values of exchangeable $\mathrm{Ca}^{+2}$ and $\mathrm{Mg}^{+2}$, available $\mathrm{K}^{+}$and $\mathrm{P}$, and organic matter. There was a predominance of Melastomataceae, Poaceae and Gleicheniaceae families, which were responsible for covering more than $90 \%$ of the gully areas. The gully areas showed pioneer plant vegetation, indicating that they are in the early successional stage.
\end{abstract}

Index terms: Water erosion, natural regeneration, plant cover.

\section{RESUMO}

Voçorocas são uma expressão da intensa degradação do ambiente, especialmente do solo e da vegetação. Objetivou-se com este trabalho caracterizar a vegetação em regeneração natural e plantada em áreas de voçorocas no Sul de Minas Gerais, Brasil, assim a distribuição e ocorrência das espécies podem gerar informações para um diagnóstico adequado sobre o estágio de desenvolvimento das voçorocas e para a conservação do solo. O estudo consistiu na caracterização da vegetação presente em diferentes segmentos das voçorocas, leito, terço médio sem vegetação (TMSV) e terço médio com vegetação (TMCV), além de um fragmento com vegetação nativa $(\mathrm{VN})$, localizado próximo às áreas das voçorocas e adotado como referência. Na área da voçoroca 3 , realizou-se o estudo em locais em que foram implantados eucalipto e candeia (Eremanthus erythropappus), sendo estes segmentos aqui denominados como terço médio com eucalipto (TME) e terço médio com candeia (TMC). A erosão hídrica impactou a cobertura vegetal, bem como alguns dos atributos do solo, especialmente nos segmento TMSV, onde a vegetação foi eliminada, em razão, principalmente, da redução dos valores de diâmetro médio geométrico dos agregados (DMG) e condutividade hidráulica do solo saturado (Ks), e aos baixos teores de $\mathrm{Ca}^{+2}$ e $\mathrm{Mg}^{+2}$ trocáveis, $\mathrm{K}^{+}$e $\mathrm{P}$ disponíveis, e matéria orgânica. Houve predomínio das famílias Poaceae, Melastomataceae e Gleicheniaceae, as quais foram responsáveis pelo recobrimento de mais de $90 \%$ das áreas das voçorocas. As áreas de voçorocas apresentaram predominantemente vegetação de plantas pioneiras, indicando que elas se encontram em estádio sucessional inicial.

Termos para indexação: Erosão hídrica, regeneração natural, cobertura vegetal.

\section{INTRODUCTION}

Among the degradation processes, water erosion in its most advanced stage, the gullies, is the most dismal (Gomide; Silva; Soares, 2011). When they are not controlled or stabilized, besides disabling areas suitable for agriculture, they can threaten roadworks and urban areas, and silt up rivers, lakes and reservoirs. Once this erosion form is established, its elimination becomes almost always unviable, stabilization remaining as an alternative to avoid the increase of the gully area (Farias et al., 1993, Goulart et al., 2006; Ferreira et al., 2011; Gomide, Silva; Soares, 2011).

An appropriate strategy for rehabilitation of degraded areas is the use of arboreal, legume and grass

${ }^{1}$ Universidade Federal de Lavras/UFLA - Departamento de Ciência do Solo/DCS - Lavras - MG - Brasil

¿Universidade Federal de São João del Rei/UFSJ - Departamento de Zootecnia/DZO - São João del Rei - MG - Brasil

${ }^{3}$ Universidade Federal de Santa Catarina/UFSC - Departamento de Microbiologia, Imunologia e Parasitologia/MIP - Trindade - SC - Brasil

${ }^{4}$ Universidade Federal de Lavras/UFLA - Departamento de Ciência do Solo/DCS - Cx. P. 3037 - 37.200-000 - Lavras - MG - Brasil - niltcuri@dcs.ufla.br

Received in september 15, 2013 and approved in november 23, 2013 
species for revegetation, however, their existence and vigor depend on the availability of nutrients and soil moisture, factors that are usually found in inadequate levels in eroded areas (Resende et al., 2007). According to Loschi et al. (2010) and Goulart et al. (2006), the knowledge of the plant species with the capacity to establish themselves in sites under adverse conditions, associated to the dispersion patterns and natural regeneration, are fundamental for the control of the erosive processes, expanding the possibilities for success of intervention aimed at the recovery of degraded areas.

According to Farias et al. (1993), the phenomenon of gully formation is as pronounced as are certain factors, such as reduced thickness of the solum (A + B horizons), small depth of $\mathrm{C}$ horizon, little coherence between the soil particles and reduced plant cover. However, when the disturbance responsible for the gully formation process ceases or is reduced, native species are capable of colonizing discontinuous sites in those areas. In the regeneration process, the time factor acts in a way to reestablish the dynamic equilibrium of the system, where the plant succession culminates in the establishment of a stable formation, that can cover the gullies entirely and exercise its primordial function.

Once established, the vegetation guarantees the soil macrofauna and the soil microbiota activity, responsible for the energy and nutrient flow in the soil-environment-plant system, also carrying out specific functions such as humus production, providing nutrients, besides contributing to plant development and soil aggregation (Moreira; Siqueira, 2006).

Works that seek to characterize the floristic composition occurring in areas altered by gully formation processes have much to contribute to programs that aim the conservation, preservation and recovery of those areas (Loschi et al., 2010). However, there are very few studies developed and published with that intention in gully areas, the works of Farias et al. (1993), Silva, Lima and Curi (1993), Loschi et al. (2010), Machado et al. (2010), Ferreira et al. (2011) and Gomide, Silva and Soares (2011) deserving prominence.

The objective of this study was to characterize the plant species present within the gully areas in order to generate useful information for an adequate diagnosis on the developmental stage of the gullies and for soil conservation.

\section{MATERIAL AND METHODS}

The study was conducted in three gully areas located in the municipal district of Lavras - MG, where the predominant soil classes are Latosols (Oxisols) and Cambisols (Inceptisols), derived from the granitic gneiss alteration (Silva; Lima; Curi, 1993). The climate of the areas is of the Cwa type according to the Köppen classification, with an average annual temperature of $19^{\circ}$ $\mathrm{C}$ and average annual rainfall of $1,530 \mathrm{~mm}$. In the soil sampling period, the temperature variation ranged from 10.0 to $33.8^{\circ} \mathrm{C}$ with an average temperature of $28^{\circ} \mathrm{C}$ and average precipitation of $14 \mathrm{~mm}$ (Meteorological Station of the Federal University of Lavras - UFLA).

The town native vegetation is represented by a mosaic of different phytophysiognomies of forest and Cerrado (Loschi et al., 2010; Queiroz et al., 1980), which were substituted by pastures and agricultural crops, only small fragments of native vegetation remaining, usually quite anthropized. The data were collected in different areas of the gullies: gully $1\left(21^{\circ} 23^{\prime} 18^{\prime \prime} \mathrm{S}\right.$ and $45^{\circ} 4^{\prime} 36^{\prime \prime}$ $\mathrm{W})$, gully $2\left(21^{\circ} 23^{\prime} 20^{\prime \prime} \mathrm{S}\right.$ and $\left.45^{\circ} 6^{\prime} 54^{\prime \prime} \mathrm{W}\right)$ and gully $3\left(21^{\circ} 20^{\prime} 43^{\prime \prime} \mathrm{S}\right.$ and $\left.45^{\circ} 12^{\prime} 43^{\prime \prime} \mathrm{W}\right)$, which are showed in figure 1 .

The study consisted of the evaluation of the soil and the vegetation in different gully segments (Figure 2): bed, bare medium third (BMT), medium third with vegetation cover (MTVC), besides a fragment with native vegetation (FNV) located closer to the gully areas and adopted as a reference. In the gully 3 area, the soil sampling took place in locations implanted with eucalyptus and candeia, aiming to minimize the erosive process of this gully area, these environments being identified as medium third with eucalyptus (MTE) and medium third with candeia (MTC).

The definition of those segments was made based on their erosive activity level and also on the vegetation presence or absence, where the FNV and MTVC are the most stable segments, the BMT segment is under continuous progress of the erosive process and the bed segment is intermediate regarding the erosive activity development pattern.

For the soil physical and chemical characterizations, soil samples were collected at a depth of $0-20 \mathrm{~cm}, 10 \mathrm{~m}$ apart, in a manner that represents the whole area of the gully. In each sampling point, ten simple samples were collected to form a composite sample. The sampling was conducted in fourteen segments of the three gully areas, four in the gully 1 , four in the gully 2 and six segments in the gully 3 , with five replications, totaling 70 samples.

The disturbed samples were collected with an auger, they were air dried and sieved through $2 \mathrm{~mm}$ openings, for determination of the chemical attributes and the particle size distribution. In the chemical characterization, the samples were analyzed according 
to the methodology of Embrapa (1997), described as follows: exchangeable $\mathrm{Ca}$ and $\mathrm{Mg}$, extracted with 1 mol L ${ }^{-1} \mathrm{KCl}$ and analyzed by titrimetry; available $\mathrm{K}$ and $\mathrm{P}$, extracted by the Mehlich-1 extractant and analyzed by colorimetry and flame photometry, respectively, and soil organic carbon by the potassium dichromate method.
The particle size distribution was determined by the pipette method, according to Embrapa (1997), using 1 mol L ${ }^{-1}$ sodium hydroxide $(\mathrm{NaOH})$ as chemical dispersant and fast shaking (12,000 oscillations per minute), during 10 minutes. The actual soil moisture was determined by the oven method at $105^{\circ} \mathrm{C}$, according to methodology described by Reichardt (1978).

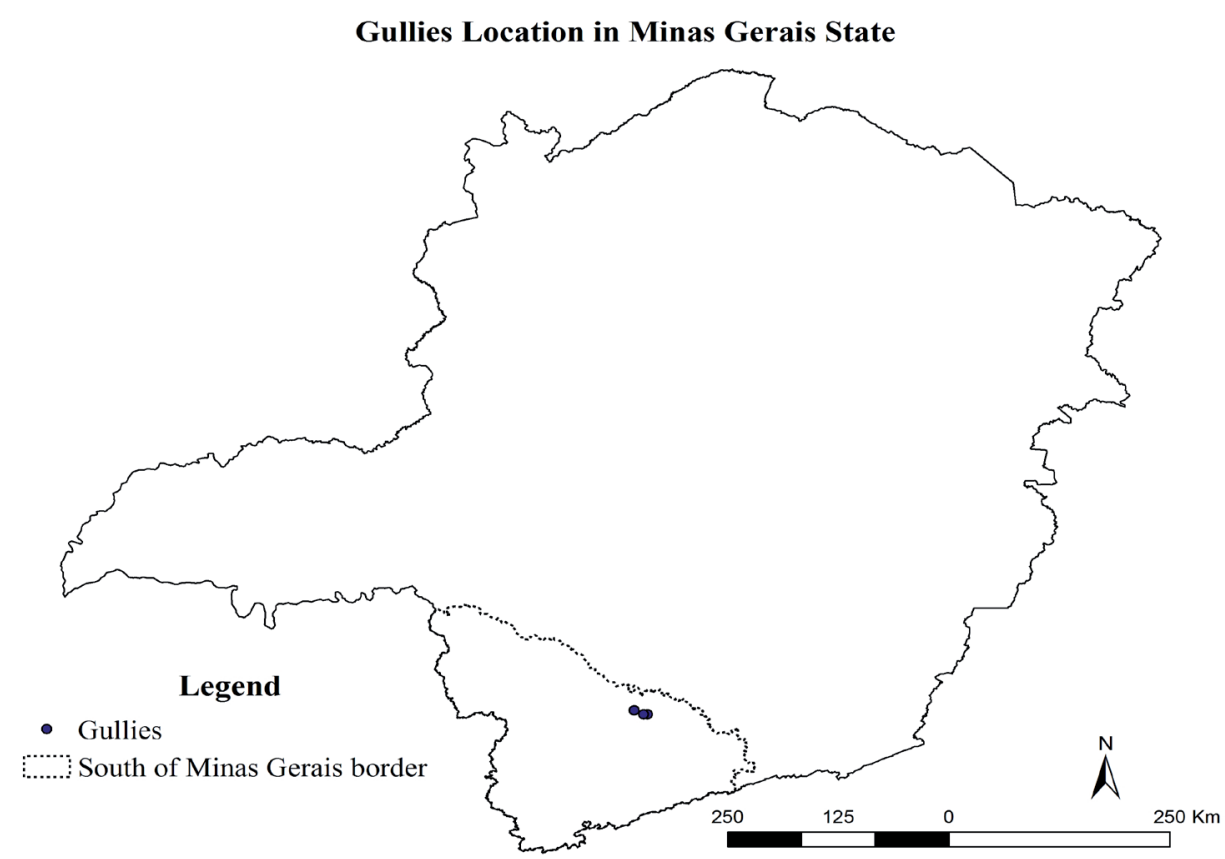

Figure 1 - Location of the studied gully areas.

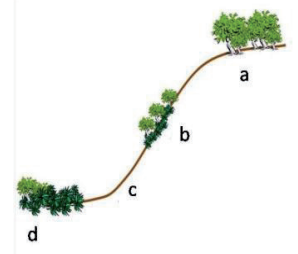

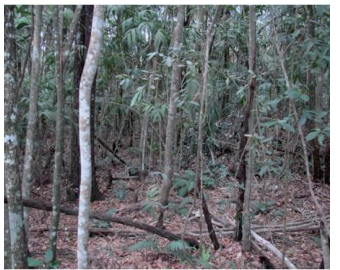

FNV (a)

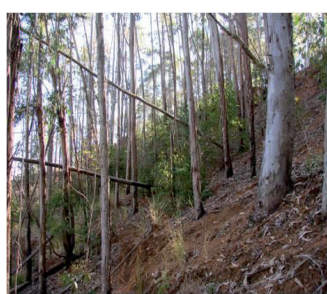

MTE (b)

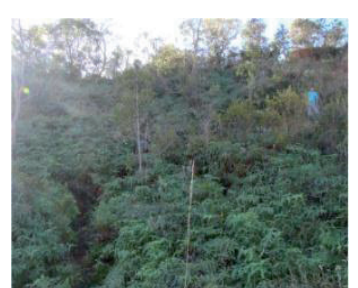

MTVC (b)

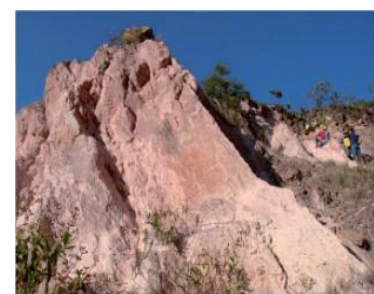

$\mathrm{BMT}(\mathrm{c})$

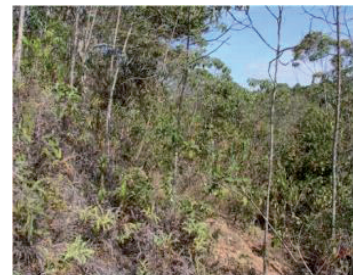

MTC (b)

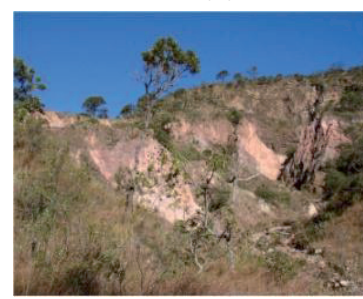

Bed (d)

Figure 2 - General scheme of sampling and photos of the gully segments: (a) fragment with native vegetation, (b) middle third with vegetation cover, (c) bare middle third, and (d) gully bed. 
Relatively to undisturbed samples, aggregates with a diameter from 4.76 to $7.93 \mathrm{~mm}$ were obtained by sieving of the soil, the stability analysis being determined through sieving in water after slow pre-wetting by capillarity (Kemper; Rosenau, 1986). Sieves of $2 \mathrm{~mm}$, $1 \mathrm{~mm}, 0.5 \mathrm{~mm}, 0.25 \mathrm{~mm}$ and $0.105 \mathrm{~mm}$ mesh were used for separation of the aggregate size classes. The geometric mean diameter (GMD) was calculated through the expression: $\mathrm{GMD}=\exp \left[\Sigma\left(\mathrm{w}_{\mathrm{i}} * \mathrm{Ln} \mathrm{x}_{\mathrm{m}}\right) / \Sigma \mathrm{w}_{\mathrm{i}}\right]$, in which GMD: geometric mean diameter $(\mathrm{mm}) ; \mathrm{w}_{\mathrm{i}}$ : mass of the aggregates of each size class $(\mathrm{g}) ; \mathrm{Ln} \mathrm{x}_{\mathrm{m}}$ : natural logarithm of the mean diameter of each size class; and $\Sigma \mathrm{w}_{\mathrm{i}}$ : total mass of sample (g).

The hydraulic conductivity of the saturated soil (Ks) was determined through constant head permeameter, following methodology described by Lima et al. (1990), with the use of undisturbed samples previously saturated by capillarity. For calculation purposes, the value stabilized after three equal readings was considered.

A floristic survey was conducted in sweeping hikes throughout all the gully areas, with the purpose of registering the shrub-tree habit species. The species were identified within each gully segment. All of the nonidentified species in the field were collected and herborized for subsequent identification in the Herbarium. The species characterized in this study were submitted to the Jaccard index, that constitutes one of the similarity indices most widely employed in studies of ecology of communities. This index compares the similarity of species that exists among successive samples in spatial and temporal intervals or along an environmental gradient. It is a binary coefficient based solely on the presence-absence ratio of the species in the compared samples. Quantitatively, the Jaccard index varies between 0 (communities totally different as to species composition) and 1 (communities totally similar as to species composition) and it is given by the following formula: $\mathrm{S}_{\mathrm{J}}=\mathrm{c} /(\mathrm{a}+\mathrm{b}+\mathrm{c})$, where: $\mathrm{S}_{\mathrm{J}}$ $=$ Jaccard similarity index; $\mathrm{a}=$ total number of species present in the condition " $\mathrm{A}$ "; $\mathrm{b}=$ total number of species present in the condition "B"; and $\mathrm{c}=$ total number of species common to conditions "A" and "B."

The results of the physical and chemical attributes were submitted to the variance analysis and average test (Scott-Knott, $5 \%$ ), by the Sisvar statistical program (Ferreira, 2011). In order to floristically compare the segments within each gully area and among the gully areas, a presence and absence matrix was elaborated with all of the species for determination of the Jaccard similarity index (Mueller-Dombois; Ellemberg, 1974). Subsequently, the analyzed attributes were submitted to the principal component analysis (PCA), with the aid of the CANOCO program, version 4.5 (Ter Braak; Smilauer, 1998). The scores were calculated for the principal components and, based on them, the materials were submitted to a grouping or cluster analysis (Mingoti, 2005; Ferreira, 2008). The base saturation (BS), organic matter (SOM) and aluminum saturation $(\mathrm{m})$ variables were transformed by the arcsine expression $(\operatorname{root}(\mathrm{x}))$, since they are proportional data (McCune; Mefford, 1999). To reduce the discrepancy among the data, the quantitative values were logarithmized $(\log (x+1))$.

\section{RESULTS AND DISCUSSION}

In the floristic survey, in the gully 1 area (Table 1), 25 species were registered with special prominence for the family of the Poaceae. In the medium third with vegetation cover (MTVC), there was predominance of species typical of the initial stages of succession, such as Gleichenia sp. and Melinis minutiflora, among other species of the family Poaceae, covering approximately $90 \%$ of the total area.

According to Farias et al. (1993), the Gleichenia sp. is almost the only species in the steep banks that compose the gully walls, corroborating with what was observed in MTVC of this gully area. According to the same authors, that dominance is due to the fact that it is a competent species regarding the covering of the soil, developing in places with little water availability and low fertility. The remainder of the area possesses species typical of the Cerrado and species of generalist occupation. These species are Stryphnodendron adstringens, Eremanthus glomerulatus, Miconia spp., Tibouchina sp., with the species Vochysia thyrsoidea, Cecropia pachystachya, Rosmarinus officinalis, Lychnophora ericoides, Baccharis trimera, Myrsine umbellata, Rudgea viburnoides, Palicourea rigida, Schefflera macrocarpa, Acosmium dasycarpum, Machaerium sp., Erythroxylum sp. and Zeyheria montana also occurring in smaller proportion (Table 1).

BMT area represents the most unstable segment of the gully area. Its position in the gully area favors the surface flow that reduces the water infiltration and, consequently, the soil moisture, besides favoring the carrying away of organic matter. In turn, the low contribution of organic matter also leads to a lower particles aggregation.

In virtue of its location, the Bed constitutes a more conservative segment, in spite of being quite stony and dry in this gully area. There was predominance of herbaceous 
vegetation with species of the family Poaceae, such as Melinis minutiflora (approximately $90 \%$ of the area), the remaining area being mainly occupied by Cerrado species and others of generalist occupation, such as Gleichenia sp., Stryphnodendron adstringens, Myrsine umbellata, Vochysia thyrsoidea, Cecropia pachystachya, Tibouchina sp., Rosmarinus officinalis, Lithraea molleoides, Roupala montana, Tapirira guianensis, Miconia albicans, Acosmium dasycarpum, Dalbergia miscolobium, coriaceous Annona and Eremanthus glomerulatus. These results corroborate the observations of Farias et al. (1993), regarding the succession of the species in a gully area. According to those authors, the grasses appear first and occupy the bottom of the gully area, where there is a drainage deficiency, together with those species that commonly participate under the same adaptive environmental conditions (low nutrient content, sandy texture and high water table).

In the gully 2 area (Table 2), 18 species were registered, with prominence for the family Melastomataceae. In the MTVC there was predominance of herbaceous shrub vegetation, with occurrence of Semidecidual Seasonal Forest species, with some elements of Cerrado. It was verified predominant occurrence of the species of the family Melastomataceae (Miconia

Table 1 - Matrix of presence or absence of species in gully 1 segments.

\begin{tabular}{|c|c|c|c|}
\hline \multirow{2}{*}{ Scientific Name } & \multirow{2}{*}{ Family } & \multicolumn{2}{|c|}{ Segments } \\
\hline & & MTVC & BED \\
\hline Acosmium dasycarpum & Fabaceae & $\mathrm{X}$ & $\mathrm{X}$ \\
\hline Annona coriacea & Annonaceae & & $\mathrm{X}$ \\
\hline Baccharis trimera & Asteraceae & $\mathrm{X}$ & \\
\hline Cecropia pachystachya & Urticaceae & $\mathrm{X}$ & $\mathrm{X}$ \\
\hline Dalbergia miscolobium & Fabaceae & & $\mathrm{X}$ \\
\hline Eremanthus glomerulatus & Asteraceae & $\mathrm{X}$ & $\mathrm{X}$ \\
\hline Erythroxylum sp. & Erythroxylaceae & $\mathrm{X}$ & \\
\hline Gleichenia sp. & Gleicheniaceae & $\mathrm{X}$ & $\mathrm{X}$ \\
\hline Lithraea molleoides & Anacardiacea & & $\mathrm{X}$ \\
\hline Lychnophora ericoides & Asteraceae & $\mathrm{X}$ & \\
\hline Machaerium sp. & Fabaceae & $\mathrm{X}$ & \\
\hline Melinis minutiflora & Poaceae & $\mathrm{X}$ & $\mathrm{X}$ \\
\hline Miconia albicans & Melastomataceae & & $\mathrm{X}$ \\
\hline Miconia spp. & Melastomataceae & $\mathrm{X}$ & \\
\hline Myrsine umbellata & Myrsinaceae & $\mathrm{X}$ & $\mathrm{X}$ \\
\hline Palicourea rigida & Rubiaceae & $\mathrm{X}$ & \\
\hline Rosmarinus officinalis & Lamiaceae & $\mathrm{X}$ & $\mathrm{X}$ \\
\hline Roupala montana & Proteaceae & & $\mathrm{X}$ \\
\hline Rudgea viburnoides & Rubiaceae & $\mathrm{X}$ & \\
\hline Schefflera macrocarpa & Araliaceae & $\mathrm{X}$ & \\
\hline Stryphnodendron adstringens & Fabaceae & $\mathrm{X}$ & $\mathrm{X}$ \\
\hline Tapirira guianensis & Anacardiaceae & & $\mathrm{X}$ \\
\hline Tibouchina sp. & Melastomataceae & $\mathrm{X}$ & $\mathrm{X}$ \\
\hline Vochysia thyrsoidea & Vochysiaceae & $\mathrm{X}$ & $\mathrm{X}$ \\
\hline Zeyheria montana & Bignoniaceae & $\mathrm{X}$ & \\
\hline
\end{tabular}

MTVC: middle third with vegetation cover; BED: gully bed. 
and Tibouchina genera), Tapirira guianensis, Protium spruceanum, Cecropia pachystachya, Rudgea viburnoides, Ocotea pulchella, Piper sp., Lamanonia ternata, Lithraea molleoides, Stryphnodendron adstringens and occurrence of the species Gleichenia sp. in some places. The genus Miconia is one of the largest of the Melastomataceae family in Brazil (Souza; Lorenzi, 2005). In general, the plants of that genus produce a great amount of seeds and their plantules can establish quickly in soils of degraded areas (Stiles; Rosselli, 1983). Vieira and Pessoa (2001) indicate that Melastomataceae species can be considered as being indicators of a high degree of soil deterioration.

The plant species identified in the gully 3 (Table 3 ) area correspond to those verified in the FNV area, an area taken as reference for this gully, floristically classified as Cerrado (sensu lato), with predominance of typical grassshrub vegetation.

In the case of the BMT segment, the presence of a few shrubs randomly distributed in the area was detected, with little herbaceous vegetation, besides presenting low moisture degree. However in the Bed, a predominance of herbaceous vegetation was verified, represented, for the most part (approximately 95\% of the area), by the species Andropogon sp. The area presents representative species of Semidecidual Seasonal Forest, with elements of Cerrado, as is noticed by the presence of the Stryphnodendron adstringens species. The lower stratum is made up by species in regeneration and bushes (the remaining area), mainly represented by the species Tibouchina $s p$., Gleichenia sp., species of the Bromeliaceae and Asteraceae family, Baccharis trimera and Lithraea molleoides. In this segment there are emergence groundwater places (swampy) that maintain high soil moisture, besides places with exposed soil. There is predominance of the species Andropogon sp, Tibouchina sp. (in regeneration) and species of the Araceae family.

The FNV segment, adopted as reference for the gully 3 area (Table 3), was classified as Semidecidual Seasonal Forest (dominant Atlantic Forest phytophysiognomy), with some elements of Cerrado, with occurrence of only two forest strata: shrub layer (predominant) and upper arboreal layer, with few emerging species.

Table 2 - Matrix of presence or absence of species in gully 2 segments.

\begin{tabular}{|c|c|c|c|}
\hline \multirow{2}{*}{ Scientific Name } & \multirow{2}{*}{ Family } & \multicolumn{2}{|c|}{ Segments } \\
\hline & & MTVC & $\mathrm{BED}$ \\
\hline Andropogon sp. & Poaceae & & $\mathrm{X}$ \\
\hline Baccharis trimera & Asteraceae & & $\mathrm{X}$ \\
\hline Cecropia pachystachya & Urticaceae & $\mathrm{X}$ & \\
\hline NI & Araceae & & $\mathrm{X}$ \\
\hline NI & Asteraceae & & $\mathrm{X}$ \\
\hline NI & Bromeliaceae & & $\mathrm{X}$ \\
\hline Tibouchina sp. & Melastomataceae & $\mathrm{X}$ & \\
\hline Miconia sp. & Melastomataceae & $\mathrm{X}$ & \\
\hline Gleichenia sp. & Gleicheniaceae & $\mathrm{X}$ & $\mathrm{X}$ \\
\hline Lamanonia ternata & Cunoniaceae & $\mathrm{X}$ & \\
\hline Lithraea molleoides & Anacardiacea & $\mathrm{X}$ & $\mathrm{X}$ \\
\hline Ocotea pulchella & Lauraceae & $\mathrm{X}$ & \\
\hline Piper sp. & Piperaceae & $\mathrm{X}$ & \\
\hline Protium spruceanum & Burseraceae & $\mathrm{X}$ & \\
\hline Rudgea viburnoides & Rubiaceae & $\mathrm{X}$ & \\
\hline Stryphnodendron adstringens & Fabaceae & $X$ & $\mathrm{X}$ \\
\hline Tapirira guianensis & Anacardiaceae & $\mathrm{X}$ & \\
\hline Tibouchina sp. & Melastomataceae & & $\mathrm{X}$ \\
\hline
\end{tabular}

NI: not identified; MTVC: middle third with vegetation cover; BED: gully bed.

Ciênc. Agrotec., Lavras, v.38, n. 2, p.149-159, mar./abr., 2014 
In the gully 3 area (Table 3), 20 species were registered. In MTVC the predominance of the species Brachiaria decumbens and representative species of the Semidecidual Seasonal Forest was verified, with some elements of Cerrado, such as Anadenanthera colubrina, Dipteryx alata, Bambusa sp., Eucalyptus sp., Casuarina sp., Miconia albicans, Tibouchina sp., Gleichenia sp., Cecropia pachystachya, Lithraea molleoides, Stryphnodendron adstringens, Rudgea viburnoides, Myrcia splendens and Myrciaria sp. A sucessional gradient can be clearly observed along this segment of the gully area, and places occupied, a portion with occupation by exotic arboreal species (Eucalyptus sp. and Casuarina sp.) and exotic herbaceous (Brachiaria decumbens). In the BMT segment, the soil supported very sparse vegetation.

In the Bed there was predominance of herbaceous vegetation with occurrence of Gleichenia sp. in its largest part (approximately $95 \%$ of the area) and occurrence of Eucalyptus sp., Casearia arborea, Eremanthus incanus, Miconia albicans and Bambusa sp. In this local there was occurrence of cattle traces and fire, however, with few places of exposed soil, and having high moisture. Besides these segments that were common to the other gully areas, there were two very steep segments covered by exotic vegetation (MTE and MTC). In MTE, the predominant presence of Eucalyptus sp., Gleichenia sp. e Miconia sp. was verified, with some individuals of Eremanthus incanus and Lithraea molleoides with incipient herbaceous vegetation. In the MTC there was dominance of the Eremanthus incanus (Candeia) species, with incipient herbaceous vegetation.

The FNV close to this gully area was classified as Semidecidual Seasonal Forest, with some species of Cerrado, such as Zeyheria tuberculosa and Caryocar

Table 3 - Matrix of presence or absence of species in gully 3 segments.

\begin{tabular}{|c|c|c|c|c|c|}
\hline \multirow{2}{*}{ Scientific Name } & \multirow{2}{*}{ Family } & \multicolumn{4}{|c|}{ Segments } \\
\hline & & MTVC & MTC & MTE & BED \\
\hline Anadenanthera colubrina & Fabaceae & $\mathrm{X}$ & & & \\
\hline Bambusa sp. & Poaceae & $\mathrm{X}$ & & & $\mathrm{X}$ \\
\hline Brachiaria decumbens & Poaceae & $\mathrm{X}$ & & & \\
\hline Caryocar brasiliense & Caryocaraceae & & & & \\
\hline Casearia arborea & Salicaceae & & & & $\mathrm{X}$ \\
\hline Casuarina sp. & Casuarinaceae & $\mathrm{X}$ & & & \\
\hline Cecropia pachystachya & Urticaceae & $\mathrm{X}$ & & & \\
\hline Dipteryx alata & Fabaceae & $\mathrm{X}$ & & & \\
\hline Eremanthus incanus & Asteraceae & & $\mathrm{X}$ & $\mathrm{X}$ & $\mathrm{X}$ \\
\hline Eucalyptus sp. & Myrtaceae & $\mathrm{X}$ & & $\mathrm{X}$ & $\mathrm{X}$ \\
\hline Gleichenia sp. & Gleicheniaceae & $\mathrm{X}$ & & $\mathrm{X}$ & $\mathrm{X}$ \\
\hline Lithraea molleoides & Anacardiacea & $\mathrm{X}$ & & $\mathrm{X}$ & \\
\hline Miconia albicans & Melastomataceae & $X$ & & & $X$ \\
\hline Miconia sp. & Melastomataceae & & & $X$ & \\
\hline Myrcia splendens & Myrtaceae & $\mathrm{X}$ & & & \\
\hline Myrciaria sp. & Myrtaceae & $\mathrm{X}$ & & & \\
\hline Rudgea viburnoides & Rubiaceae & $\mathrm{X}$ & & & \\
\hline Stryphnodendron adstringens & Fabaceae & $\mathrm{X}$ & & & \\
\hline Tibouchina sp. & Melastomataceae & $\mathrm{X}$ & & & \\
\hline Zeyheria tuberculosa & Bignoniaceae & & & & \\
\hline
\end{tabular}

MTVC: middle third with vegetation cover; MTC: middle third with candeia; MTE: middle third with eucalyptus; BED: gully bed. 
brasiliense, in initial stage of succession. The border of the upper limit of the gully area possesses an herbaceous and shrub incipient layer, with exotic arboreal individuals, such as Eucalyptus sp. On the border of the lower limit of the gully area the formation of Semidecidual Seasonal Forest prevails in a more advanced stage of succession, with predominance of typical arboreal species of this formation.

In general, the three gully areas presented pioneer plant vegetation, that is common in degraded and/or disturbed systems (Tabarelli; Mantovani, 1999). The predominance of the pioneer species verified in the gully areas indicates that they are found at the initial sucessional stage (Corrêa; Melo Filho, 2007). They are considered colonizing species and they evidence their importance in the initial phase of the vegetation recovery process. These results were also observed by Loschi et al. (2010) who evaluated the floristic and structural variations of a gully area in Itumirim, in southern Minas Gerais.

In order to floristically compare the segments within each gully area and among the gully areas, a presence or absence matrix (Table 1, 2 and 3) was elaborated with all of the species for determination of the Jaccard similarity index. This was $0.4,0.11$ and 0.28 for the segments of the gully 1, 2 and 3 areas, respectively. According to Kent and Coker (1992), values higher or equal to 0.5 indicate high similarity. Therefore, according to that concept, the similarity analyzed among the gully segments can be considered as low, indicating that the floristic composition in those gully areas is considerably different.

Furthermore, the low similarity estimated within the gully segments and among the gully areas $(\mathrm{Sj}=0.19)$ in this study reinforces the fact that the conservation of this vegetation is fundamental for the community to reach a higher biodiversity.

The principal component analysis (PCA) and cluster analysis demonstrated, through the ratio between principal component 1 (PC1) and principal component 2 (PC2), that there was separation among the segments of the studied gully areas (Figure $3 \mathrm{a}, \mathrm{b}$ and c). In the gully 1 area, the PCA and cluster results showed clearly that the FNV and MTVC segments differed from the Bed and BMT, separated by PC1, this being aided by the chemical and physical attributes SOM and GMD, respectively (Figure 3a). The attributes SOM, K, GMD and Ds were those that most influenced the separation of FNV from the other segments. In the gully 2 area, results similar to those of the gully 1 area were observed, the BMT segment separated from the others by PC2; the physical (Ds and MP) and chemical attributes ( $\mathrm{pH}, \mathrm{Al}$ and $\mathrm{m}$ ) were those that most contributed to that separation (Figure $3 \mathrm{~b})$. In the gully 3 area, FNV and MTVC grouped with chemical attributes $\left(\mathrm{Ca}^{+2}, \mathrm{Mg}^{+2}, \mathrm{SB}, \mathrm{BS}, \mathrm{Al}, \mathrm{H}^{+}+\mathrm{Al}^{3+}, \mathrm{T}\right.$, $\mathrm{P}$ and SOM) being separated from the other segments (Bed, BMT, MTE and MTC), which grouped with Dp (Figure 3c).

The principal component analysis and cluster analysis showed, besides the spatial separation of the studied areas, that there were differences in the distribution of the analyzed attributes, so that some of them were more sensitive to the damage caused by the water erosion, distinguishing the more degraded segments, such as BMT and Bed, from those that showed to be more stabilized, like MTVC and the reference areas. As such, the identification of chemical and physical attributes presents potential for use as disturbance indicators, which enables their use for soil quality monitoring (Melloni; Siqueira; Moreira, 2003). It is known that the highest or lowest sensitivity of each attribute in the segments of the studied gully areas is due to, among other factors, the climatic conditions, the type of soil management, the history of the area, the soil chemical and physical conditions, as well as the amount and quality of the plant residue. As such, the water erosion in its most advanced form, gully formation, acts in a negative way on the chemical and physical attributes of the soil.

As a recommendation of species to reestablish areas degraded by hydric erosion, primarily gully areas, the pioneer species are the most recommended because they colonize the area, giving evidences of their importance in the early phases of the recuperation process due to their capacity of growing under unfavorable or even extreme environmental conditions in relation to other plant species. Out of the recommended plant families, Poaceae, Gleicheniaceae e Melastomataceae showed the best development. In these restrictive environmental conditions, grassy vegetation such as Melinis minutiflora, Adropogon sp., Brachiaria sp., and bracken (Gleichenia sp.), this latter being considered the only capable of colonizing the steep slope segments within the gully areas, present an outstanding capability of adaptation and covering the soil. The herbaceous-shrubby vegetation is highlighted by the Melastomataceae family and the genera Miconia and Tibouchina. The use of arboreal species to refrain the erosion should be avoided, mainly on gully areas of steep slopes. 
(a)
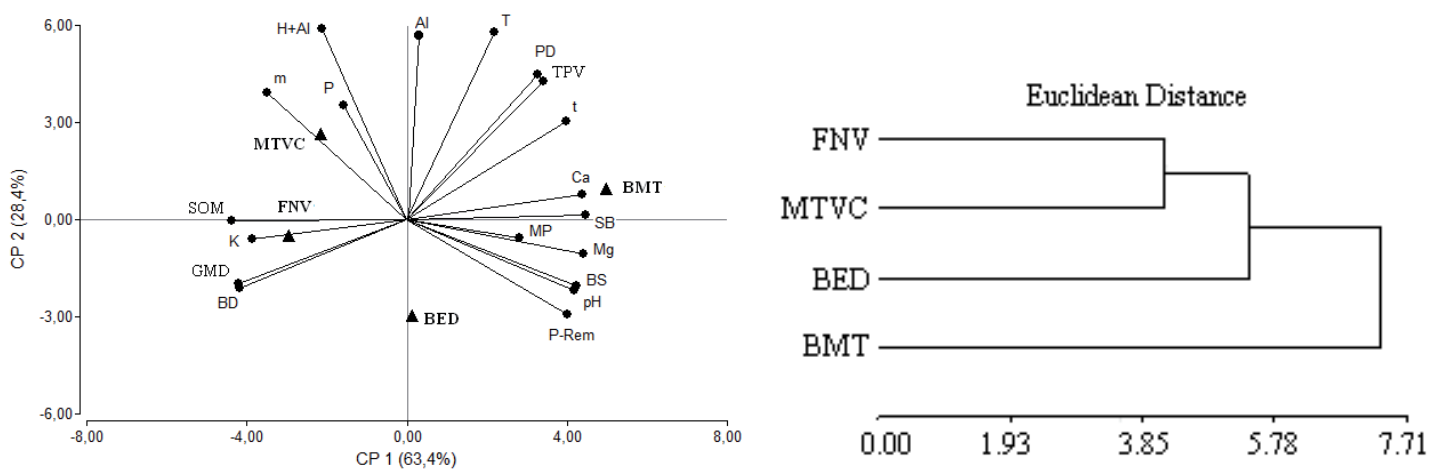

(b)
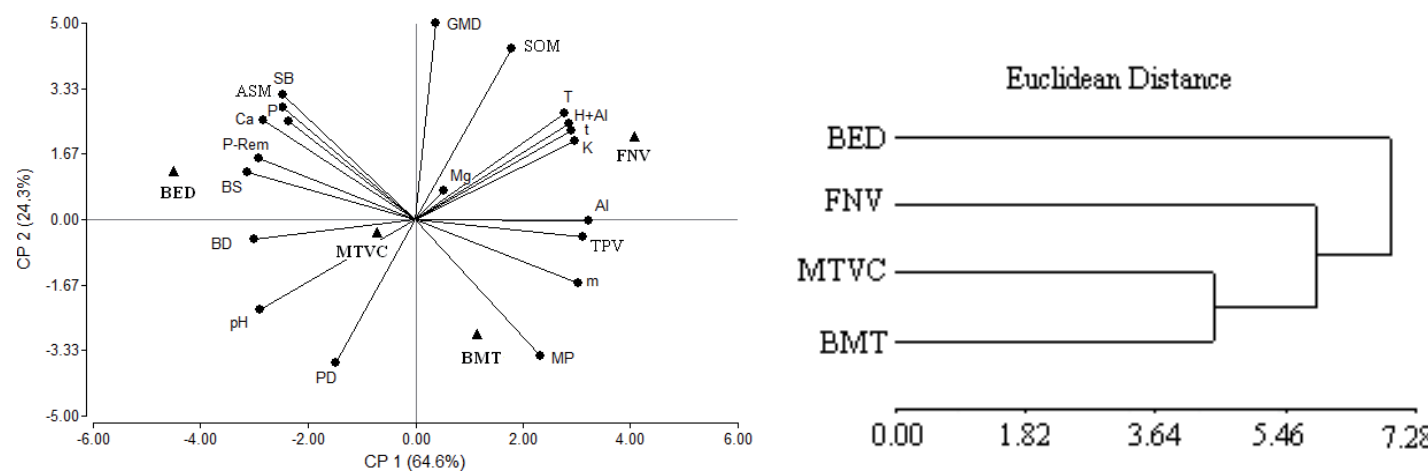

(c)
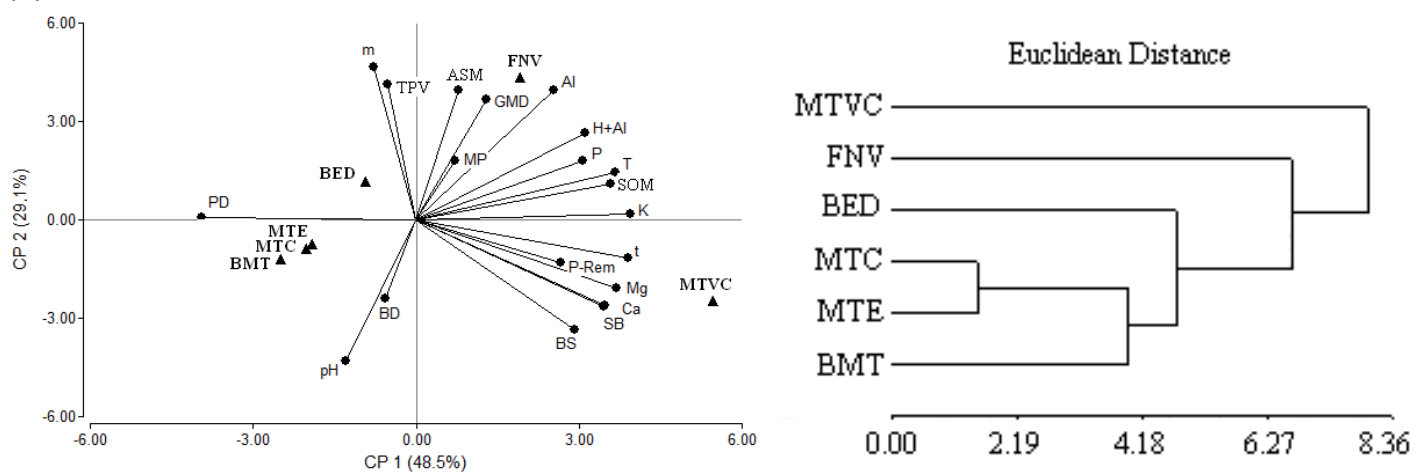

Figure 3 - Relationship between Principal Component 1 (PC1) and Principal Component 2 (PC2) and cluster analysis detailing the gully segments in gully 1 (a), gully 2 (b) and gully 3 (c) areas, respectively. Explanatory chemical and physical variables: $\mathrm{pH}, \mathrm{P}, \mathrm{K}^{+}, \mathrm{Ca}^{+2}, \mathrm{Mg}^{+2}$; $\mathrm{SOM}$ : organic matter; $\mathrm{SB}$ : sum of bases; BS: base saturation; m: aluminum saturation; $\mathrm{Al}^{3+}$; t: effective CEC and T: potential CEC; P-rem: remaining phosphorus; $\mathrm{BD}$ : bulk density; PD: particle density; TPV: total pore volume, MP: macroporosity; GMD: geometric mean diameter of aggregates.

\section{CONCLUSIONS}

The physical and chemical attributes were sensitive to reflect the damage caused by the water erosion, that can be observed in the BMT segments of the gully areas.
The gully areas under study present pioneer plant vegetation, indicative of the initial sucessional stage, with predominance of the families Poaceae and Melastomataceae.

In the Bed of the gully areas, in function of the restrictive environmental conditions, there was the 
establishment and predominance of herbaceous vegetation, such as grasses and ferns (Gleichenia sp.).

The segments within the gully areas presented considerably different floristic composition, also verified among the gully areas, reinforcing the need for conservation of this vegetation for the community to reach a higher richness.

The herbaceous-shrubby species found in the floristic survey can be of great usefulness in gully area recovery, since they exhibit indications of the ability to develop under environmental conditions unfavorable or extreme for the survival of other plants.

The reduction of values of physical and chemical attributes of the soil caused by water erosion, showed the principal component analysis spatial separation of degraded segments (BMT, BED) of those more established (MTVC and reference areas), demonstrating that the presence of vegetation contributes to improving such soil attributes.

\section{ACKNOWLEDGEMENT}

To the Fundação de Amparo à Pesquisa do Estado de Minas Gerais (FAPEMIG), for the funding of this study, under Project CAG APQ 3776.3.08/07.

\section{REFERENCES}

CORREAA, R.S.; MELO FILHO, B. Levantamento florístico do estrato lenhoso das áreas mineradas no Distrito Federal. Revista Árvore, 31(6):1099-1108, 2007.

\section{EMPRESA BRASILEIRA DE PESQUISA}

AGROPECUÁRIA - EMBRAPA. Centro Nacional de Pesquisa em Solos. Manual de métodos de análises de solo. 2.ed. Rio de Janeiro: Ministério da Agricultura, 1997. $212 \mathrm{p}$.

FARIAS, C.A. et al. Dinâmica da revegetação natural de voçorocas na região de Cachoeira do Campo, município de Ouro Preto - MG. Revista Árvore, 17(3):314-326, 1993.

FERREIRA, D.F. Sisvar: a computer statistical analysis system. Ciência e Agrotecnologia, 35(6):1039-1042, 2011.

FERREIRA, D.F. Estatística multivariada. Lavras: UFLA, 2008. 672p.

FERREIRA, V.M. et al. Influência antrópica e atributos de solo: inter-relações em ambientes de voçorocas na mesorregião Campos das Vertentes, MG. Geografia, 36 (1):209-219, 2011.

GOMIDE, P.H.O.; SILVA, M.L.N.; SOARES, C.R.F.S. Atributos físicos, químicos e biológicos do solo em ambientes de voçorocas no município de Lavras - MG. Revista Brasileira de Ciência do Solo, 35(2):567-577, 2011.

GOULART, R.M. et al. Caracterização de sítios e comportamento de espécies florestais em processo de estabilização em voçorocas. Cerne, 12(1):68-79, 2006.

KEMPER, W. D; ROSENAU, R. C. Aggregate stability and size distribution. In: KLUTE, A. (Ed.). Methods of soil analysis part 1: Physical and Mineralogical methods. Winsconsin: ASA/SSSA, v. 1, n. 9, p.425-442. 1986.

\section{KENT, M.; COKER, P. Vegetation description} analyses. London:Behaven Press, 1992. 363p.

LIMA, J.M. et al. Dispersão do material de solo em água para avaliação indireta da erodibilidade de Latossolos. Revista Brasileira de Ciência do Solo, 14(1):85-90, 1990.

LOSCHI, R.A. et al. Variações florísticas e estruturais de uma voçoroca em Itumirim, Minas Gerais. Cerne, 16(4):479-498, 2010.

MACHADO R.L. et al. Soil and nutrient losses in erosion gullies at different degrees of restoration. Revista Brasileira de Ciência do Solo, 34(6):945-954, 2010.

McCUNE, B.; MELFFORD, M. J. M. Multivariate analysis of ecological data. Gleneden Beach: MjM Softwae, 1999. CD-ROM.

MELLONI, R.; SIQUEIRA, J.O.; MOREIRA, F.M.S. Fungos micorrízicos arbusculares em solos de área de mineração de bauxita em reabilitação. Pesquisa Agropecuária Brasileira, 38(2):267-276, 2003.

MINGOTI, S.A. Análise de dados através de métodos de estatística multivariada: Uma abordagem aplicada. Belo Horizonte: UFMG. 2005. 297p.

MOREIRA, F.M.S.; SIQUEIRA, J.O. Microbiologia e bioquímica do solo. Lavras: UFLA, 2006. 626p. 
MUELLER-DOMBOIS, D.; ELLEMBERG, H. Aims and methods of vegetation ecology. New York:John Wiley \& Sons, 1974. 547p.

QUEIROZ, R. et al. Zoneamento Agroclimático do Estado de Minas Gerais. Belo Horizonte: Epamig, 1980. 114p.

REICHARDT, K. A água na produção agrícola. 1. ed. São Paulo: McGraw-Hill, p.1-119. 1978.

RESENDE, M. et al. Pedologia: base para distinção de ambientes. Lavras: Editora Ufla, 2007. 322p.

SILVA, A.C.; LIMA, J.M.; CURI, N. Relação entre voçorocas, usos da terra, solos e materiais de origem na região de Lavras (MG). Revista Brasileira de Ciência do Solo, 17:459-464, 1993.

SOUZA, V.C.; LORENZI, H. Botânica sistemática: guia ilustrado para identificação das famílias de angiospermas da flora brasileira, baseado em APG II. Nova Odessa:Instituto Plantarum, 2005. 640p.

STILES, F.G.; ROSSELLI, L. Consumption of fruits of the Melastomataceae by birds: how diffuse is coevolution? Vegetatio, 107/108(1):57-75, 1983.

TABARELLI, M.; MANTOVANI, W. A regeneração de uma floresta tropical montana após corte e queima (São Paulo - Brasil). Revista Brasileira de Biologia, 59(2):319-328, 1999.

TER BRAAK, C.J.F.; SMILAUER, P. CANOCO reference manual and user's guide to Canoco for

Windows: software for canonical community ordination (version 4). New York: USGS, 1998. 352 p.

VIEIRA, C.M.; PESSOA, S.V.A. Estrutura e composição florística do estado herbáceo-subarbustivo de um pasto abandonado na Reserva Biológica de Poço das Antas, município de Silva Jardim, RJ. Rodriguésia, 52(80):17-30, 2001. 